\title{
A different perspective on operations systems classifications
}

\author{
S.R. van der Walt \\ School of Business Leadership, Unisa, P.O. Box 392, Pretoria 0001, Republic of South Africa
}

Received 6 August 1990; accepted 31 October 1990

\begin{abstract}
The student in the field of operations management often encounters the problem of why and how the management approach of one type of operations system differs from another. In the operations literature these differences are mostly explained by referring to the process structure in the case of manufacturing operations. In the case of service operations the differences are often explained by referring to the differences between services and manufacturing. These explanations are unsatisfactory, particularly in the light of modem technologies, and sometimes emphasise what is being done in the operations system rather than looking at the approach which should be followed or how the generation of the output should be managed. The management approach is more important to the student in this field. The objective of this study is to identify those dimensions or factors that have been used in the literature to describe the nature and management approach of operations systems, to analyse the underlying meaning thereof, and to isolate those dimensions that independently influence the management approach of operations systems.

'n Probleem wat studente soms in die veld van bedryfsbestuur ondervind, is om te bepaal waarom en hoe die bestuursbenadering van een tipe bedryfseenheid van dié van 'n ander verskil. In die bedryfsliteratuur word die verskille tussen bedryfseenhede meestal aan die hand van die prosesstruktuur in die geval van vervaardiging, en aan die hand van die verskille tussen dienste en vervaardiging in die geval van diensbedrywe, verklaar. Hierdie verklarings is, veral in die lig van moderne tegnologie, ontoereikend en lê dikwels klem op wat daar in die bedryfseenheid gedoen word, eerder as op die benaderings wat gevolg word om die uitsette te lewer. Vir die student in die vakgebied van bedryfsbestuur, is die benadering wat gevolg word om uitsette te lewer belangriker, aangesien dit die wyse waarop die bedryfseenheid bestuur word, bepaal. Hierdie ondersoek het ten doel om daardie dimensies of faktore wat in die literatuur gebruik word om die aard en bestuursbenadering van bedryfseenhede mee te beskryf, te identifiseer, vir onderliggende betekenis te ontleed en daardie dimensies wat die bestuursbenadering onafhanklik van mekaar bepaal, uit te sonder.
\end{abstract}

\section{Introduction}

The student and manager in the field of operations management frequently encounter the problem of how to manage a specific operations system or how the management of one operations system differs from that of another. The subject literature provides many classifications in an effort to solve this problem. The use of most of these classifications is unfortunately limited due to the bases being applied in differentiating between the different operations systems. Most classifications are based on the nature of the output or on the nature of what is being done. When dealing with the production or generation of the output, management approaches and systems are based on the nature of operations systems and the process, i.e. on how the output is generated and not only on what is being generated or produced.

What is needed is a classification based on a set of independent factors or dimensions with appropriate scales that can be applied universally on any type of operations system. An operations system is defined here as a set of elements that transforms a set of input elements into a set of output elements. This definition allows for the inclusion of any type of work group. Such a set of dimensions can be used as a model that typifies operations systems with regard to the nature and management approach applied. This would have a widespread application in developing organisation structures, teaching operations management, and relating management styles and approaches to types of operations systems. It would also be useful in comparative studies; results of research on the effect of technology on organisation structure are in some cases not comparable due to the various bases used to measure technology, to mention but one area of conflict (Fry and Slocum, 1984: 223).
In an effort to develop such a model, popular classifications have been analysed for comprehensiveness and applicability. The most useful ones have been combined into one universal classification, which served as the basis for this research. Furthermore, the existing literature has been surveyed for those factors that influence or determine the nature and management approach of operations systems. These factors were then applied to the universal classification to test whether the classification distinguishes between different types of operations systems from a management point of view.

\section{Traditional operations system classifications}

Five classifications for operations systems, which served as a basis for this research, are discussed below.

\section{The classification according to the process structure}

The most popular classification for manufacturing operations is the process structure (Schmenner, 1990:: 241). According to this classification, manufacturing operations can be grouped into job shop, batch flow, worker paced assembly line, machine paced assembly line, and continuous flow processes. This classification is very useful in that it distinguishes between operations systems on the basis of product variety, output rate, layout and degree of standardisation, i.e. those factors that are important for the management of the system. Some authors, like Sasser et. al. (1978: 81), applied this classification to service operations as well. The process structure unfortunately does not distinguish between high and low technology systems.

The underlying continuum in the process structure scale is the degree of rigidity in flow pattern. This sometimes 
implies an increasing level of automatisation but not necessarily so. Hull and Collins (1987: 788) developed subcategories for the batch flow process, namely the traditional and technical batch processes, in an effort to distinguish between high and low technology. By identifying two categories, they merely drew the attention to the shortcoming of the process structure. It is not sufficient to use only two categories for technology for classification purposes. Also, the process structure does not distinguish between discrete and process production, a dichotomy discussed by Timms and Pohlen (1970: 28) as being an important factor affecting the management approach.

\section{The classification developed by Menipaz}

Menipaz (1984: 8) classified all operations into production, service, transpor, supply (e.g. retail) and storage types. Menipaz also acknowledged ownership as an unique factor influencing the nature and management approach of operations systems. The process structure mentioned above, is only applicable to the production and to a lesser extent to low contact services (Chase, 1978: 138).

Other authors of operations management text books (eg. Schmenner, 1986 and Sasser et. al., 1978) also stress the difference between manufacturing and service as if an operations system belongs to either one or the other. A more modern approach is to realise that operations systems can be classified on a continuum ranging from the extreme service system to the extreme manufacturing system (McClain \& Thomas, 1985: 9).

\section{The classification developed by Wild}

The classifications above, do not distinguish between operations systems on the basis of the status of inventory. An operations system, where raw materials and final stock could be held, is managed differently from one where no such stocks could be held. Wild (1984: 10) took this aspect into account in his classification. He classified operations systems into seven groups depending on whether raw material, final stock or both could be held in production systems and whether clients could be queued up or not in service systems.

\section{The classification developed by Thomas}

In an effort to distinguish between all the service types, Thomas (1978: 8) used two bases. Firstly, the method of generating the service could be either man or machine based. Secondly, the man based operations could be separated on the basis of skill required to render the service and the machine based operations could be separated on the basis of the level of automatisation applied. Although useful, this classification is based on only three factors that influence the management approach.

\section{The classification developed by Fitzsimmons and Sullivan}

Another useful classification is the one of Fitzsimmons and Sullivan (1982: 16). This classification uses the overall function and type of client as basis and is based on two main categories:
A service can be rendered:

- to a client, or

- for a client.

Services rendered to a client can be subcategorised into people processing and people changing services. People processing include services like medical examinations, court hearings, employment agencies, etc. People changing services include surgery, education, church, etc.

Both these subcategories could be further divided into voluntary and involuntary services.

Service for a client, according to Fitzsimmons and Sullivan, can be summarised as facilitating something for the client: transport, communication, finance, accommodation and recreation.

\section{The classifications combined}

The classification of Fitzsimmons and Sullivan covers a wide range of services but is still limited. Repair, supply (including production) and consulting services could also be added to the services for a client. This classification, therefore, appears not to be exhaustive but provides a practical basis for a universal classification.

A classification based on the logic of Fitzsimmons and Sullivan, but at the same time incorporating the thinking of the authors mentioned above, was developed for the purpose of this research. Table 1 represents this universal classification. The classification is based on the premise that all operations systems can be grouped into one of the following main classes:

I - What is being done to people

II - What is being done for people

III - What is being done to property of people

It is believed that this universal classification covers all types of operations systems. It would appear to represent some of the more popular classifications found in the published literature.

\section{Dimensions of the operations space}

It has not been proved that the classification in Table 1 distinguishes between operations systems on the basis of the management approach required for operations systems. A literature survey (Van der Walt: 1990) indicated that there are more than 60 various dimensions that influence or determine the nature and the management approach needed for operations systems. The research of Woodward (1970), Perrow (1970) and Thompson (1967) proved to be most useful in this regard. Many dimensions, however, appear to be describing the same concepts while others combine some basic concepts. These dimensions were therefore analysed for obvious commonalities. For this purpose it was first of all necessary to define an operations system. Following that, recognition was given to a need to define the phrase 'determine the nature and management approach' before the dimensions identified in the literature could be analysed.

With regard to the first problem, an operations system was defined as any, and the smallest section or workgroup, whether part of an organisation or on its own, where products or services are generated by a specific group of people and/or machines headed by the lowest level of supervision. The definition had to be kept wide to include 
any type of workgroup. The reason for the qualification of the lowest level of supervision was to ensure that workgroups generating different types of products or services but reporting to the same manager, were not combined or taken as one. This approach was recommended and followed by researchers like Comstock and Scott (1977: 177), Fry and Slocum (1984: 222) as well as Alexander and Randolph (1985: 845).

The second problem concerned the definition of the dimensions to be included in this research. Important here was the way an operations system should be managed. This includes the decisions relating to capacity, location, type of process and technology, organisation structure, planning and control of output, inventory, quality, labour force and maintenance; all those topics normally covered in operations management courses. All dimensions that have an influence on these management aspects, were analysed.

As could be expected, many dimensions had the same meaning. The analysis resulted in 17 dimensions that could be regarded as basic dimensions for the purpose of this research, each influencing or determining the way an operations system is being managed in a unique way. These are:
- Size as measured in terms of the output rate

- Size as measured in terms of the number of workers

- Level of formal education

- Form of the product or service

- Uncertainty of the specification

- Uncertainty of the method or task

- Variety of products or services

- Flexibility of the process

- Level of automatisation of the process

- Level of labour intensity

- Task interdependence

- Storability of the product or service

- Measurability of the product or service

- Degree of cost competitiveness

- Degree of freedom to deviate from specification

- Competitiveness based on timeous delivery

- Degree of freedom in determining the delivery date/time.

It was suspected that the above-mentioned dimensions were not necessarily independent; some might still have the same underlying meaning. To gain more clarity on the dependency amongst these dimensions, scales were developed to measure these dimensions in various types of operations

Table 1 Universal operations system classification

\begin{tabular}{|c|c|c|c|c|c|}
\hline \multicolumn{6}{|c|}{ Group I: What is being done to people: } \\
\hline \multirow[t]{2}{*}{1.0} & Processing & 1.1 & Involuntary & & \\
\hline & or evaluating: & 1.2 & Voluntary & & \\
\hline \multirow[t]{2}{*}{2.0} & Changing: & 2.1 & Involuntary & & \\
\hline & & 2.2 & Voluntary & & \\
\hline \multicolumn{6}{|c|}{ Group II: What is being done for people: } \\
\hline \multirow[t]{2}{*}{3.0} & Transport: & 3.1 & Standard routes & & \\
\hline & & 3.2 & Customised routes & & \\
\hline \multirow[t]{10}{*}{4.0} & Supply: & 4.1 & Commercial: & 4.1 .1 & Selling \\
\hline & & & & 4.1.2 & Buying \\
\hline & & 4.2 & Mining or & 4.2.1 & Known yield \\
\hline & & & fishing: & 4.2.2 & Unknown yield \\
\hline & & 4.3 & Construction & & \\
\hline & & 4.4 & Production: & 4.4.1 & Non-discrete standard \\
\hline & & & & 4.4 .2 & Non-discrete customised \\
\hline & & & & 4.4.3 & Discrete standard \\
\hline & & & & 4.4.4 & Discrete customised \\
\hline & & & & 4.4 .5 & Agriculture \\
\hline \multirow[t]{8}{*}{5.0} & Services: & 5.1 & \multicolumn{3}{|l|}{ Facilizating } \\
\hline & & 5.2 & \multicolumn{3}{|c|}{ Representating (Agencies) } \\
\hline & & 5.3 & \multicolumn{3}{|l|}{ Professional } \\
\hline & & 5.4 & \multicolumn{3}{|l|}{ Entersaining } \\
\hline & & 5.5 & \multicolumn{3}{|l|}{ Public } \\
\hline & & 5.6 & \multicolumn{3}{|l|}{ Risk } \\
\hline & & 5.7 & \multicolumn{3}{|c|}{ Communication } \\
\hline & & 5.8 & \multicolumn{3}{|c|}{ Staff functions (in organisations) } \\
\hline
\end{tabular}

Group III: What is being done to propeny of people

6.0 Proted

7.0 Transporn: 7.1 Standard routes

7.2 Customised routes

8.0 Evaluate

9.0 Store

10.0 Change/repair 
systems and to determine if any correlations exist between them. The scales used are discussed below.

\section{Output rate}

Output rate is mostly defined in terms of the form of the product or service (e.g. tons per hour, standard hours per day). This complicates the use of this dimension in comparative studies. It was therefore assumed that output rate is a function of the number of workers and the level of automatisation applied in the operations system, of which both are regarded as basic dimensions.

\section{Number of workers}

Number of workers is a simple quantifiable scale.

\section{Level of formal education}

Four categories were used, namely: no education; can read and write; standard 8,10 or technical college; university, technicon or professional education. From this information, various ratios were calculated to express the level of education of the subunits.

\section{The form of the product or service}

The dimension of form was found difficult to quantify. It was assumed in this research that the form of a product or service is represented in terms of the units of output (e.g. tons per hour, standard hours per day or money eamed per day). This measurement was not successful. Similar operations systems reported various units of output, especially those in the service industry.

This dimension was eliminated from the research assuming that the form will have a major influence on the technology and equipment used, but not necessarily on the management approach. It was also believed that other dimensions like storability, measurability, level of automatisation, level of labour intensity and task interdependance cover the managerial aspects of the dimension of form. However, this assumption is open for criticism.

\section{Uncertainty of specification and of task}

Uncertainty of specification has the same meaning as Perrow's exceptions, while uncertainty of task has the same meaning as Perrow's analysability (Perrow, 1970: 75). Withey, Daft and Cooper (1983: 59) tested a number of scales that had been used for Perrow's two dimensions of exceptions and analysability. Two scales which loaded high on exceptions and analysability respectively, and which are easy to apply to any type of operations system, were used in this questionnaire.

Chase (1978: 137) developed a model for relating customer contact to various management aspects. Contact is the ratio of direct contact time to the total time taken to service the customer. Chase also related some management approaches to contact time. If contact time could be simply measured in any type of operations system, it would have assisted a great deal in this research. Preliminary studies, unfortunately, showed that in most cases it was impossible to measure contact time accurately. Respondents had difficulty in estimating the direct contact time or total time taken to service clients. Conceptually contact might be related to the level of uncertainty of the needs of the customer. Customer contact was therefore regarded as being covered by uncertainty of the specification.

A scale, measuring the percentage of orders or consultations that were unique with regard to the previous year, was also used for this dimension.

\section{Variety of products or services}

Two scales were used here, namely number of different products and number of product lines. The first scale turned out to be better understood in all types of operations systems.

\section{Flexibility of the process}

The only scale that could be developed for flexibility was the time taken or needed for changing over from one product or service to another. This scale turned out to be unpractical. The distribution was highly scew to the right and only a few respondents in the service industry could determine this value.

\section{Level of automatisation}

Two scales were used in the pilot test. The first one was the capital intensity scale by Marsh and Mannari (1981: 37). This scale measures the ratio of fixed assets per worker. Respondents seemed to have difficulty in calculating the ratio due to the lack of information. The different accounting approaches used by companies led to uncomparable ratios. This scale also appeared to be inaccurate when applied to the service industry. This was probably due to the low capital intensity of the industry.

The second scale was the one originally developed by Amber and Amber (1962: 2) and which was extensively used by other researchers like Hickson (1969: 382), Blau et. al. (1976: 23) and March and Mannari (1981: 56). This scale applied the principle whereby the following three levels of work are sequentially being taken over by machines as the level of automatisation rises:

- mechanical work (leverage applied)

- electrical work (other sources of energy)

- intelligent work (information, feedback, decisions).

Although this scale has been proven reliable in the manufacturing environments, no evidence could be found of its applicability in the service industry. The scale was adapted to include mechanical aids used in the service industry.

Marsh and Mannari summarised the measurement of the highest level of automatisation and the level of automatisation of the majority of equipment. The reason for this was based on the fact that the level of automatisation required for the tasks in companies ranges from zero to the highest level found there. A company will not use a specific level of automatisation for all the tasks. It was assumed that, for the purpose of this research, this summation was not necessary on work unit level and that the highest level of automatisation would greatly influence the management approach followed there.

Level of labour intensity

Although evidence had been found that labour intensity is 
indirectly proportional to the level of automatisation (Khandwalla, 1977: 460 and Schmenner, 1986: 21), it was decided to include a separate scale for this dimension. The claimed relationship is based on manufacturing operations and is not necessarily valid for service operations.

Three scales were employed to test various bases for this dimension. All scales measured the direct labour cost as a percentage of three different costs. Firstly as a percentage of direct product or service cost (material, labour and utilities), secondly as a percentage of total product or service cost and thirdly as a percentage of product or service price.

\section{Task interdependence}

The scales found in the available literature were all designed for a specific type of operations system (Kiggundu, 1981: 499). For the purpose of this research, a scale was developed that measures the extent of rigidity in the sequence of tasks.

\section{Other scales}

The scales for the remaining dimensions were all based on the five point Likert type, measuring the extent to which:

1. a product or service can be stored,

2. a product or service can be physically measured,

3. cost competition is experienced,

4. the specification of a product or service can be deviated from,

5. the delivery date can be deviated from, and

6. freedom in determining the delivery date or time is allowed.

\section{Research methodology}

The research problem could be stated as follows:

Whether the basic dimensions chosen are practically measurable and whether the scales used are universally valid and reliable (Leedy, 1985: 25). The scales must be usable in manufacturing, service, or any type of operations system and still be interpretable.

Whether there is, underlying to the 17 basic dimensions, a smaller number of independent dimensions that describe the operations space.

Whether this smaller number of independent dimensions distinguishes between the different classes of the universal operations classification.

The universe of interest is all existing operations systems. This is not known and it was thus impossible to sample the universe for research purposes. Another constraint on this research was the fact that the respondents should have a basic knowledge of operations management and terms used. It was therefore decided to use the Alumni of the School of Business Leadership of Unisa. The Alumni represent a wide range of operations systems and they understand the terms used in this research. However, it was realised that due to the nature of the questionnaire, the fact that the respondents will not gain from responding and the fact that some Alumni have to delegate the completion of the questionnaire to the required level in the organisation, the response rate would be low. To ensure a workable response of at least 100 questionnaires, 4000 questionnaires were sent out. The requirement of 100 usable questionnaires was derived using the rule of Hair, Anderson and Tatham (1987: 237). According to this rule, one would need at least four completed questionnaires for each variable in the questionnaire to apply correlation and factor analyses.

The response rate was satisfactory for this purpose; 366 questionnaires were returned representing 22 of the classes of the universal classification. The classes included representatives of all five classes of Menipaz's classification, namely production, service, storage, supply and transport.

The reliability and validity of the scales used, were tested in a pilot study. Fifty respondents returned the questionnaire of the pilot study and some were followed up with personal interviews. Although many scales existed for most of the dimensions, the majority of those scales were applicable to a sub set of the operations space. One example is the scale for measuring the level of automatisation in the manufacturing environment which had not been validified in the service environments before.

The interval scales that were used, were of the five point Likert type with descriptions only at the two extreme values of the scale. This was done intentionally to allow the use of these scales in factor analyses. The assumption was made that the intervals between any two points on the scales were equal (Hanke, Reitsch and Dickson, 1984: 19 \& 460).

Some scales, like the number of workers, were not linear and needed to be transformed. Pearson correlations were calculated to study the effect of these transformations. This correlation matrix was also used to determine which scales were to be used in follow-up analyses. Those dimensions with low correlations $(<0,3)$ with others were taken as being independent, providing the independence was conceptually acceptable. These independent dimensions were therefore not used in the factor analysis. Principle component factor analysis with accompanying Varimax rotation was applied to the remaining basic dimensions. Only factors with an Eigenvalue higher than one were taken as being meaningful.

Those operations classes with more than six responses were selected for the purpose of studying the third problem. The distribution of these classes is represented in Table 2. Averages of the measurements of the independent dimensions for each of the classes were calculated. The significance of the differences between the averages, were studied by using ANOVA. The extent to which the averages of the operations classes under test differed from each other, was established by applying the Bonferroni-t-test to the averages.

\section{Results and interpretation}

Dimensions that seemed to be independent and therefore not used in the factor analysis, were the following:

- Level of automatisation

- Number of workers

- Variety of products or services

- Storability

- Degree of cost competitiveness

- Degree of freedom to determine the delivery date/time

- Competitiveness based on timeous delivery 
Table 2 Distribution of the classes represented by the respondents

\begin{tabular}{llc}
\hline & \multicolumn{1}{c}{ Class } & Number of respondents \\
\hline 2.2 & Voluntary change & 8 \\
4.1 .1 & Selling & 27 \\
4.2 & Mining & 9 \\
4.3 & Construction & 6 \\
$4.4 .1 \& 2$ & Production: non-discreat & 16 \\
$4.4 .3 \& 4$ & Production: discreet & 66 \\
4.4 .5 & Agricultural & 7 \\
5.2 & Agency services & 13 \\
5.3 & Professional services & 50 \\
5.8 & Staff function services & 101 \\
8.0 & Evaluating services & 9 \\
10.0 & Change, repair services & 31 \\
\hline
\end{tabular}

The results of the factor analysis are represented in Table 3. Three factors with Eigenvalues greater than one were identified.

Factor one represents all those dimensions and scales related to the uncertainty of specification and task. These dimensions constitute the model of Perrow and it would appear as if they also represent Thompson's task interdependence. Brewer (Woodward, 1970: 21) claimed that standardisation is the underlying dimension to Woodward's classification, which is, if analysed carefully, also based on the level of uncertainty. It would therefore be appropriate to allocate the name 'level of standardisation' to factor one.

It is important to note the high loadings on factor one of two dimensions that would be thought of as independent,

Table 3 Results of the principle factor analysis

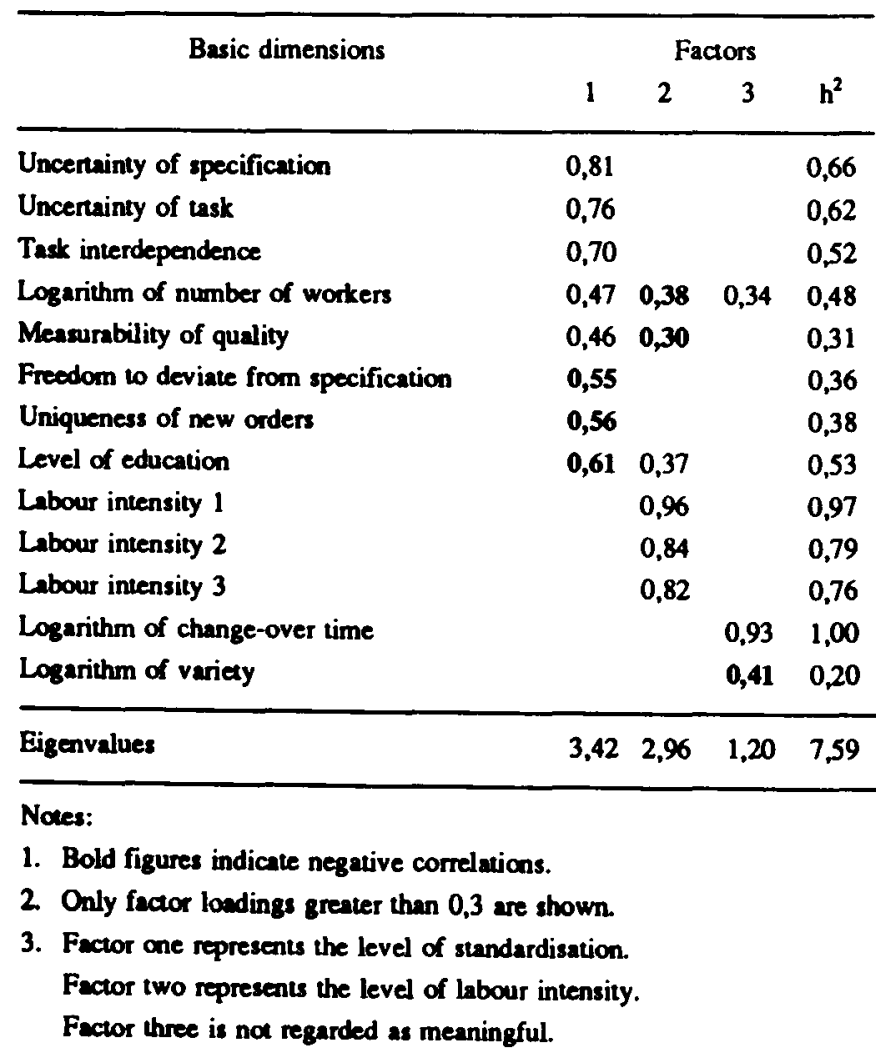

namely, measurability of quality and freedom of deviation from the specification. The first one represents the extent to which the quality of output can be measured and can be related to the tangibility of a product or service. The high loading could be due to the fact that as the level of standardisation increases, so does the measurability in most cases. Services tend to be lesser standardised and therefore less measurable. This relationship is not always true, especially in the manufacturing environment. While this dimension loads high $(0,46)$ on factor one, it is suggested that it should be regarded as independent until further research prove otherwise.

The second one, namely the freedom of deviation from the specification, represents the level of competition based on quality. The same reasoning is applicable in this case: there is a possibility that the more a product or service is standardised, the lesser it will compete on the basis of quality. This is not necessarily true in all cases and it is suggested that this dimension should also be regarded as independent until further research is done.

Factor two represents the three labour intensity scales. Due to the common factor of direct labour, it could be expected that these scales will load high on one factor. The importance here is the fact that no other meaningful loading or correlation was observed. The correlation between automatisation and labour intensity, described by Khandwalla and Schmenner, is not supported in this research. The reason could be twofold: the scales used might not be accurate or reliable, or the stated relationship is only valid in certain operations systems, e.g. some manufacturing units. Further research is underway in an effort to study the components of the dimension of automatisation. It would appear as if automatisation is a combination of two other independent dimensions. These could be the level of mechanisation (the extent to which machines take the labour over from man) and judgement (the extent to which the judgemental or intelligence work is taken over by machines).

Factor three combines the remaining dimensions and is not regarded as meaningful. As described earlier, the measurement of change-over time was not accurate enough to be meaningful. There is sufficient evidence in the literature that variety and number of workers are independent. The low correlations and loadings on the factors seem to support this statement.

The independent dimensions identified here were:

- Level of standardisation

- Measurability of quality

- Degree of freedom to deviate from specification

- Labour intensity

The results of the ANOVA analysis (the investigation of the third problem) were all negative. None of these in dependent dimensions appeared to distinguish between any of the classes of the universal classification that have been used. This indicates some support to the statement that the existing classifications mainly describe the different forms of output or what is being done by the operations system. The independent dimensions describe those factors that determine or influence the way the output generation is managed which is the important concern in this study. 


\section{Conclusion}

When the dimensions indentified above are analysed for sources of origin, they could be grouped into three categories:

The nature of the product or service determines the:

- Level of standardisation

- Variety

- Storability

- Measurability of quality

The nature of the process determines:

- The number of workers

- The level of automatisation

- The extent of labour intensity

The nature of the market determines:

- The extent of cost competition

- The extent of freedom in determining the delivery date

- The extent of freedom in deviating from the specification

- The extent of competition based on timeous delivery.

These independent dimensions form a model that appears to determine or influence the nature and management approach of any type of operations system. It should provide a better basis for distinguishing between various types of operations systems than the universal or any traditional operations system classification that has been discussed here.

Although this model has some limitations, it is a point of departure for a practical operations classification. Research is underway to clarify some uncertainties. With a refined model, it would be possible to study the management approaches that are applied to different successful operations systems. This will be of great assistance in teaching, consulting and applying operations management principles and techniques.

\section{References}

Alexander, J.W. \& Randolph, W.A. 1985. The fit between technology and structure as a predictor of performance in nursing subunits. Academy of Management Journal, Vol. 28, No. 4, 844-859.

Amber, G.S. \& Amber, P.S. 1962. Anatomy of outomation. Englewood Cliffs: Prentice-Hall.

Blau, P.M., Falbe, C., Mckinley, W. \& Tracey, P.K. 1976. Technology and organisation in manufacturing. Administrative Science Quarterly, Vol. 21, 20-40.

Chase, R.B. 1978. Where does the customer fit in a service operation? Harv. Bus. Rev., Nov/Dec., 137-142.

Comstock, D.E. \& Scott, W.R. 1977. Technology and the structure of subunits: Distinguishing individual and workgroup effects. Administrative Science Quarterly, Vol. 22, 177-203.

Fitzsimmons, J.A. \& Sullivan, R.S. 1982. Service operations management. New York: McGraw-Hill Book Company.

Fry, L.W. \& Slocum, J.W. Jr. 1984. Technology, structure and workgroup effectiveness: a test of a contingency model.
Academy of Managemens Journal, Vol. 27, No. 2, 221-246.

Hair, J.E., Anderson, R.E. \& Tatham, R.L. 1987. Multivariate data analysis with readings. 2nd Edition. New York: Macmillan Publishing Company.

Hanke, J., Reitsch, A. \& Dickson, J.P. 1984. Statistical decision models for management. London: Allen and Bacon, Inc.

Hickson, DJ., Pugh, D.S. \& Pheysey, D.C. 1969. Operations technology and organization structure: an empirical reappraisal. Administrative Science Quarterly, No. 14, 378-397.

Hull, F.M. \& Collins, R.D. 1987. High-technology barch production systems: Woodward's missing type. Academy of Management Journal. Vol. 30, No. 4, 786-797.

Khandwalla, P.N. 1977. The design of organizations. United States of America: Harcourt Brace Jovanovich, Inc.

Kiggundu, M.N. 1981. Task interdependence and the theory of job design. Academy of Management Review, Vol. 6, No. 3, 499-508.

Leedy, P.D. 1985. Practical research. Planning and design. 3rd Edition. New York: Macmillan Publishing Company.

McClain, J.O. \& Thomas, L.J. 1985. Operations management production of goods and services. New Jersey: Prentice-Hall, Inc.

Marsh, R.M. \& Mannari, H. 1981. Technology and size as determinants of the organizational structure of Japanese factories. Administrative Science Quarterly. Vol. 26, 33-57.

Menipaz, E. 1984. Essentials of production and operations management. Englewood Cliffs: Prentice-Hall, Inc.

Perrow, C. 1970. Organizational analysis. A sociological view. California: Wadsworth Publishing Company.

Sasser, W.E., Olsen, R.P. \& Wyckoff. O.D. 1978. Management of service organisations. Text and cases. Boston: Allyn \& Bacon.

Schmenner, R.W. 1986. How can service business survive and prosper. Sloan Managemen Review, Spring, 21-32.

Schmenner, R.W. 1990. Production/operations management concepts and situations. 4th Edition. Chicago: Science Research Associates.

Thompson, J.D. 1967. Organisations in action. New York: McGraw-Hill Book Company.

Timms, H.L. \& Pohlen, M.F. 1970. The production function in business. 3rd Edition. Illinois: Richard D. Irwin.

Thomas, D.R.E. 1978. Strategy is different in service business. Harv. Bus. Rev., Jul/Aug, No. 78411, 5-12.

Van der Walt, S.R. 1990. Dimensies wat die aard en bestuursbenadering van bedryfseenhede bepaal. Doctoral thesis. Pretoria: University of South Africa.

Wild, R. 1984. Production and operations management. Principles and techniques. 3rd Edition. East Sussex: Holth Rineholt and Winston Lid.

Withey, M., Daft, R.L. \& Cooper, W.H. 1983. Measures of Perrow's work unit technology: An empirical assessment and a new scale. Academy of Management Journal, Vol. 26. No 1. 45-63.

Woodward, J. (Ed.) 1970. Industrial organization. Behaviour and control. London: Oxford University Press. 